\title{
Effects on milk yield and composition of infusions of volatile fatty acids and caseinate into the digestive tract of dairy cows
}

\author{
C Hurtaud, H Rulquin, R Vérité \\ INRA, Station de Recherches sur la Vache Laitière, \\ Saint-Gilles, 35590 L'Hermitage, France
}

Changes in milk secretion and composition, particularly an increase in protein, have been obtained by increasing either the proportion of energy mainly as propionic acid or the availability of amino acids. It can be questioned whether these responses are additive or whether associative effects exist between energy levels and nitrogen levels (Rulquin, 1982).

Ruminal isoenergetic infusions of either a low (17 $\mathrm{mol} / \mathrm{day}$ of $64 \%$ acetic, $21 \%$ propionic and $15 \%$ butyric acids) or high propionic acid mixture (13.4 mol/day of propionic acid) were factorially combined with duodenal infusion of either sodium caseinate $(500 \mathrm{~g} / \mathrm{d})$ or control.

Four ruminally and duodenally fistulated Holstein cows were used 4 months post partum in a $4 \times 4$ Latin square (2 weeks/period). The diet was limited so that with infusions, energy and nitrogen needs were met and consisted of $60 \%$ maize silage, $10 \%$ hay, $21.5 \%$ energy concentrate and $7.5 \%$ soya bean meal.
Duodenal infusion of casein increased milk yield $(+1.9 \mathrm{~kg})$ and significantly decreased milk fat content $(-2 \mathrm{~g} / \mathrm{kg})$ $(P<0.1)$. Milk protein and casein content increased $(+2.1$ and $1.7 \mathrm{~g} / \mathrm{kg}$ respectively).

The propionic infusion caused a large increase in rumen propionate $(+14.0 \%$ units). Milk yield tended to decrease $(-1.6 \mathrm{~g})$ and milk fat decreased significantly $(-5.4 \mathrm{~g} / \mathrm{kg})(P<0.01)$. There was no change in protein or casein content.

There was no interaction between energy and casein as observed by Lough et al (1983). We conclude that the effects of propionic acid on milk composition seen previously were due more to changes in energy levels than to changes in energy source.

Lough DS, Prigge EC, Hoover WH, Varga GA (1983) J Dairy Sci 66, 756-762

Rulquin H (1982) Reprod Nutr Dev 22, 905921

Table I. Effect of infusions of volatile fatty acids and caseinate on rumen volatile fatty acids and on milk yield and composition.

\begin{tabular}{llllll}
\hline Nitrogen & \multicolumn{2}{c}{ Low } & \multicolumn{3}{c}{ High } \\
Propionic acid & Low & High & Low & High & SE \\
\hline $\mathrm{C}_{2} / \mathrm{C}_{3}$ in rumen & $4.0 \mathrm{~B}$ & $1.5 \mathrm{~A}$ & $3.3 \mathrm{~B}$ & $1.9 \mathrm{C}$ & 0.3 \\
Milk yield $(\mathrm{kg} / \mathrm{d})$ & 25.6 & $23.0 \mathrm{a}$ & $26.7 \mathrm{~b}$ & 25.6 & 1.7 \\
Milk lat content $(\mathrm{g} / \mathrm{kg})$ & $38.7 \mathrm{~B}$ & $34.4 \mathrm{a}$ & $37.6 \mathrm{~B}$ & $31.5 \mathrm{~A}$ & 1.5 \\
Milk protein content $(\mathrm{g} / \mathrm{kg})$ & 30.1 & 29.6 & 30.8 & 30.8 & 1.1 \\
Milk casein content $(\mathrm{g} / \mathrm{kg})$ & 24.3 & 24.5 & 25.6 & 25.8 & 1.4 \\
\hline
\end{tabular}

A, B, C : $p<0.01 ; a, b: p<0.1 . C_{2}$ : acetic acid. $C_{3}$ : propionic acid. 